\title{
"A Detailed Research Study on Work-Life Balance of Working Women Employees in An Academic Sector"
}

\author{
Brahmjot Bagga $^{1}$ ， Dr. Unmesh Mandloi ${ }^{2}$ \\ ${ }^{1}$ Research Scholar, APJ Abdul Kalam University, Indore. \\ ${ }^{2}$ Asst. Professor, APJ Abdul Kalam University, Indore.
}

\begin{abstract}
It has expanded the commitment of Indian women in the economy of family and country. However, what might be said about the harmony between their work life and everyday life. For that reason, such review has been led and the information has been gathered from the female respondents of schooling area. It has been coming out that females are confronting trouble in dealing with their own and expert life simultaneously.

The public authority of Indian just as of states and others also are pushing for expanding the commitment of ladies in the general public for that the public authority has presented booking for ladies just as age limit has been expanded for applying to government occupations for ladies.
\end{abstract}

Keywords: Female employees, work life balances, Indian public authority.

\section{INTRODUCTION}

Indian families are going through fast changes because of the urbanization and modernization. Indian working women having a place with all classes entered to occupations so they can bring in some cash. As of now, openness of Indian ladies to instructive freedoms is higher than it was a few decades prior, particularly in the metropolitan region. This has opened new vistas as well as expanded mindfulness and raised goals of self-improvement. This, alongside monetary strain, has been instrumental in affecting women's choice to enter the work power. Most investigations of utilized wedded ladies in India have revealed monetary need as being the fundamental explanation given for working.

The situation with Indian ladies has been dependent upon numerous extraordinary changes in the course of recent many years. During antiquated days ladies has been loved as goddesses.

International Business Report (IBR) of business consultancy uncovers that the extent of Indian ladies was involving senior situations in business has launch from $9 \%$ in 2011 to $14 \%$ in 2012. All the more significantly the quantity of ladies' CEOs has hopped from $1 \%$ in 2011 to $10 \% 2012$, when internationally the number rose from $8 \%$ to $9 \%$.

The inescapable idea of desire and yearning among Indian ladies is unprecedented with an incredible $80 \%$ contrasted with $52 \%$ in the U.S. The amazing degrees of want among Indian ladies have been fueled by the country's quick financial development that has achieved a change in the societal position of ladies. In any case, Indian ladies faces special social and cultural difficulties that crash their craving and contrive to compel ladies to one or the other settle for impasse occupations or leave the labor force. The exploration builds up that the rich ability pool of school taught hopeful ladies holds the way in to the ferocious battle for high-echelon ability that multinationals experience as they pin their development possibilities on unique quickly developing economies like India.

Circumstances are different. From the time the spouse acquired, and the wife remained at home. To the time now when the spouse acquires and the wife procures as well. Yet, the spouse actually cooks and washes and runs the house. Things being what they are, how can she offset her work with life at home?

Throughout the long-term females in India have attempted to set up a personality and make an imprint in the social just as in the authoritative stages, however with instructive organizations preparing an ever-increasing number of women to enter proficient professions, have definitely changed the situation.

\section{REVIEW OF LITERATURE}

The research on Work-life Balance has been built out considering its acquired prominence with the significant intend to have flourishing of society and the acknowledgment of satisfying lives for its representatives by supporting the development of each worker and the further improvement of the organizations. In this paper, an undertaking has been made to give an outline of different parts of Work-Life Balance through the audit of existing writing. The sources alluded incorporate different diaries, books, doctoral proposal, working research papers, reports, magazines, websites, papers and 


\section{International Advanced Research Journal in Science, Engineering and Technology}

\section{Vol. 8, Issue 12, December 2021}

\section{DOI: $10.17148 /$ IARJSET.2021.81219}

so on and has been referred. The writing distinguishes its impact on different quality life conditions like Work Stress, Job Satisfaction, Career Growth, Turnover, Appraisal, Absenteeism, Appreciation and serious climate in setting with Work-life Balance and its arrangements.

Ghaji Badawi (2006) studied, "the Job satisfaction among female librarians in Nigeria". Herzberg theory of motivation was highlighted in this. The study was conducted on females in Nigeria to collect information with job satisfaction. Descriptive statistics was used to evaluate data. The study concluded that librarians were condemn with their achievement, relationships, growth, and recognition. He also mentioned dissatisfaction of female employees that was because of hardships to follow organizational policies, working conditions \& poor administration.

Shah and et. al. (2012) clarified in their exploration that, 'the prize and acknowledgment, oversight and work itself had decidedly impacted the work fulfillment and representatives were not seen as much happy with the actual work in contrast with management and award and acknowledgment'. Which essentially tells that representatives requires some sort of inspiration that might be inherent or outward to work successfully and with fulfillment. This might be made conceivable through some sort of acknowledgments given to the resources.

Lockwood (2013) in his book in, 'work life balance/ challenge \& solution' detailed about that to have an equilibrium state of work life balance focusing on wellbeing of employees, mental \& physical health is utmost requirement specially to working women as they hold many responsibilities.

M.S. Uddin (2013) et al. explained their study in Bangladesh on female teachers. The stated that female teacher's job \& family have a dual dependency on work life balance. Their study revealed that women need to have a highlight on some factors such as crèches, child care centers, and transport allowances, flexible hours of working etc. to have an effective work life balance.

\section{RESEARCH METHODOLOGY}

The information has been gathered exhaustive the organized poll. The example size was 40 and every one of the respondents were from the training area. The assortment strategy was helpful inspecting. With the attainment of goal \& information examination through various test has been applied with the use of SPSS and where required the information has been given the assistance of Pie diagram.

\section{FINDINGS}

H01 There is no critical distinction in the mean worth of women representatives investing a lot of energy at work place. The invalid theories have been dismissed $(\mathrm{p}<0.05)$, henceforth one might say that there is huge contrast in the mean worth of women representatives investing a lot of time at work place. Investing more energy at work spot might be because of that speed the female representatives are slow or the idea of the work given to them is tedious.

H02 There is no critical contrast in quality time enjoying with loved ones because of work. The invalid speculations have been dismissed $(\mathrm{p}<0.05)$, subsequently one might say that there is a huge distinction in quality time enjoying with loved ones because of work. The explanation might be that they are not getting sufficient spare energy after their work or because of some different obligations.

H03 There is no huge contrast in the mean worth of ladies' respondents ponder work when they are not at work. The invalid theories have been dismissed $(\mathrm{p}<0.05)$, consequently one might say that there is a critical distinction in the mean worth of ladies' workers contemplating the work.

H04There is no huge distinction in issues in family because of office work of women employees. The invalid theories have been dismissed $(\mathrm{p}<0.05)$, thus there is a huge contrast in family issues because of office work of women representatives. The explanation might be that the work gets impacted at home on account of the workplace work.

H05 There is no critical distinction in fulfillment of female representatives by association backing to deal with the family issues. The invalid theories have been dismissed $(\mathrm{p}<0.05)$, one might say that there is a critical distinction in satisfaction of ladies' workers by association backing to deal with the family issues.

The dependability score of the information gathered to investigate, with the end goal of this undertaking was 0.90 , which affirms that the information gathered was exceptionally solid, as the inquiries were extremely important, the respondents could comprehend the inquiries and the polls were not tedious as the reactions were organized.

Besides this the study depicted that $68 \%$ of women respondents belongs to age group (chart 1) $25-35$, $44 \%$ of them are in management \& commerce graduates, (table 2), chart 3 tells abou the salary which is $62 \%$ in category of $20000 \&$ above. 
Vol. 8, Issue 12, December 2021

DOI: $10.17148 /$ IARJSET.2021.81219

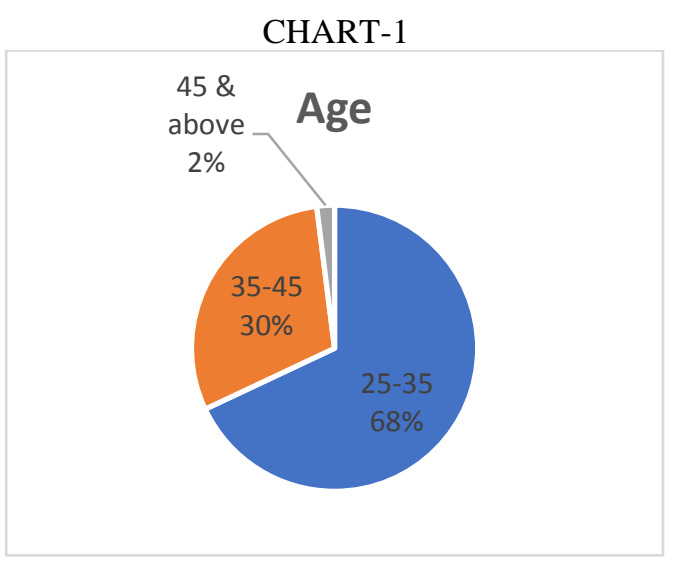

CHART-2

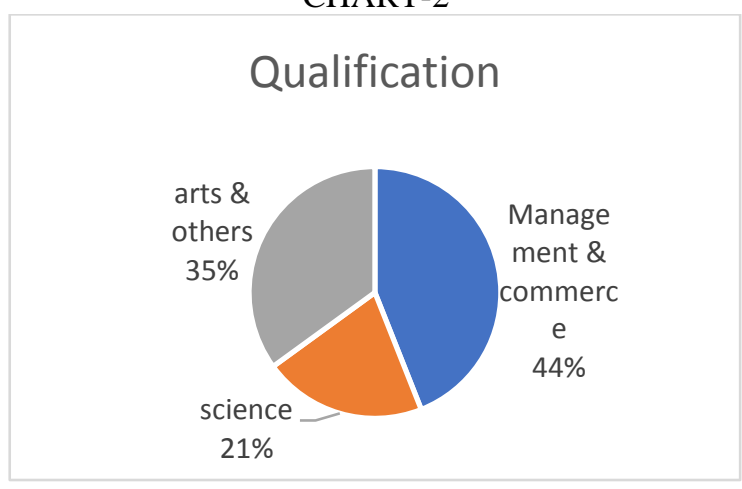

CHART-3

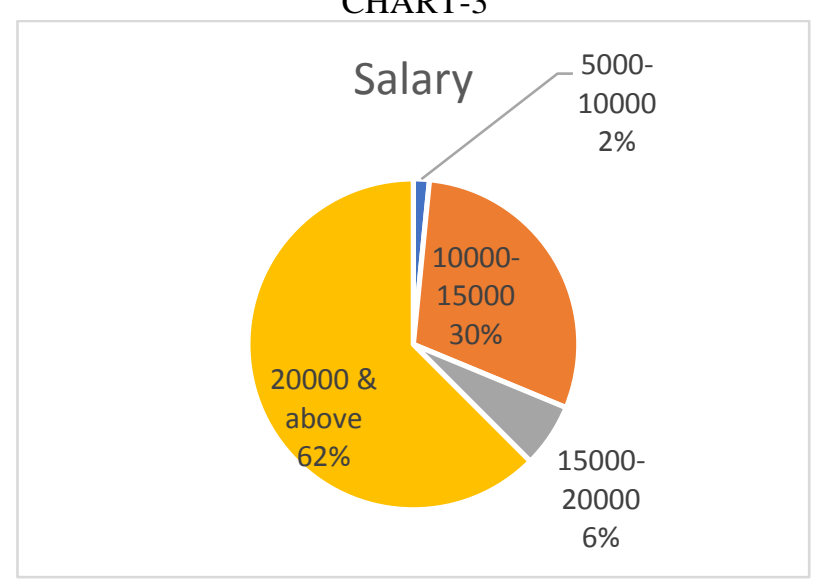

\section{CONCLUSION}

There is enormous challenges for the working women to make a balance between the expert life and the individual life. Working women are confronting a few kinds of issue at the work place as well as at their home. They are assuming to oversee both the closures with completely of productivity and exactness. They are assuming twofold part in their life yet up how much they had the option to deal with and manage their twofold obligations become significant. It tends to be finished up ladies' representatives are intellectually involved with regards to the workplace work committing additional time in office which influences their homegrown obligations which influences their demeanor. Despite the fact that they are taking care of both the obligations they are not happy with the workplace support in dealing with their homegrown issues. Because of that their homegrown issues influences their expert work and tight clamp versa. Albeit the justification for such disparity might be expected the that the age bunch which they have a place larger part of them are between 25 35 , their compensation, experience and capability. 
International Advanced Research Journal in Science, Engineering and Technology

Vol. 8, Issue 12, December 2021

DOI: $10.17148 /$ IARJSET.2021.81219

\section{REFERENCES}

1) Badawi, Ghaji (2006) "Factors affecting the level of Job Satisfaction of female librarians in Nigeria: A Test of Herzberg Hygiene or Motivator Factors". Samaru Journal of Information studies, Samaru Journal of Information Studies Vol. 6 no. 1 \& 2, pp.6-12.

2) Shah, M. J., Rehman, M.U., Akhtar, G., Zafar, H. and Riaz, A. (2012). "Job Satisfaction and Motivation of Teachers of Public Educational Institutions.” International Journal of Business and Social Science, 3(8), 271-281.

3) Sharma U. New Delhi: Mittal Publishers; 2006. Female labour in India. [Google Scholar]

4) M.S. Uddin, A.M.A. Mamun, Nazamuland Hoque 2013, "Work-Life Balance: A Study on Female Teachers of Private Education Institutions of Bangladesh", European Journal of Business and Management, Vol. 5, No. 13, pp. 10-17.

5) http://adapt.it/adapt-indice-a-z/wp-content/uploads/2014/06/lockwood_work_life_balance_2003.pdf

6) https://bmcpublichealth.biomedcentral.com/articles/10.1186/s12889-020-09139-w 